\title{
The Effect of Financial Crises on Growth and FDI in some African Countries: A Panel VECM Approach
}

\author{
Mary O. Oche, Yohane Khamfula and Gisele Mah*
}

\author{
School of Economics, North West University, South Africa
}

\begin{abstract}
This study investigates the effects of financial crises on economic growth and foreign direct investment in some African countries. A panel vector error correction model is used for the analysis of annual time series data for the period 1994 to 2014. From economic growth model, in the long run, it is observed that gross domestic product per capita is positively influenced by investment, trade and foreign direct investment; with investment and trade being statistically significant. Gross domestic product per capita has a negative significant relationship with real effective exchange rate. On the other hand, in the long run, the investment model shows that investment has a significant positive relationship with both gross domestic product per capita and investment; while it has a negative significant relationship with real effective exchange rate and trade. Also observed from the results is that financial crisis has a negative relationship with both economic growth and foreign direct investment. This study recommends more openness of the economy so as to promote both economic growth and inflow of foreign direct investment in countries. It also recommends the need to encourage more gross fixed capital formation in order to promote both economic growth and foreign direct investment.
\end{abstract}

Keywords: Financial Crisis, Foreign Direct Investment, Economic Growth and Panel Vector Error Correction Model.

\section{INTRODUCTION}

Since the early 1980s, the global economy has witnessed a number of financial crises. These episodes of financial crises have profoundly affected developing and emerging economies. The fundamental question in this regard is whether these economies have experienced higher economic growth rates and attracted increased foreign direct investment during the financial crises. The main objective of this study is to build macro-econometric models that are capable of explaining the growth and inflow of FDI in the economies of some African countries with specific interest in the impact of financial crisis on economic growth and FDI in these economies. The study uses a panel data set to analyse the effects of financial crises on economic growth and foreign direct investment for the period $1994-2014$. The study is crucial as it will contribute to literature since not much empirical work has been done in regard of the some African economies. Also, this study is the only one that simultaneously examines the impact of financial crisis on both economic growth and FDI by building two econometric models that will help to capture the effects of the financial crisis variable.

Since the great depression in 1930, many economies experienced financial crisis. Financial crisis happens when some financial assets suddenly lose a large part of their nominal value. In the global

*Address correspondence to this author at the School of Economics, North West University, South Africa; E-mail: Gisele.Mah@nwu.ac.za

JEL Classification: $\mathrm{H} 6, \mathrm{O} 4$. economy, the term financial crisis is a very familiar term as there have been a series of different types of financial crisis. One of severe financial crisis occurred during the period 2008/2009; this financial crisis was said to have been caused by the subprime mortgage meltdown in the United States (Avgouleas, 2008). This occurred in the financial system where paper assets were generated whose value depends on housing prices. The assumption was that there would be continuous rise in home prices and that, if there is fluctuation in the price, the value of the assets could still be determined. This, however, did not come to pass. There was a fall in the price of houses and the value of the assets could not be determined. Thus, the American financial system was left in tailback, and this spread over to Europe where the paper assets have been bought by many financial institutions. As noted by Gros \& Alcidi (2010), the 2008/2009 financial crisis had left the global economy with adverse downturn. Its impact on macroeconomic policy and the Gross Domestic Product (GDP) was felt for a while.

According to Furceri and Mourougane (2009), the fall in potential GDP for 30 members of Organisation for Economic Co-operation and Development (OECD) countries is estimated to be about $1.5 \%$ and $2.5 \%$ after a recession; while with a chronic recession, the fall in GDP is estimated to be up to $4.0 \%$. In the same vein, the estimates of the International Monetary Fund (IMF) suggest that the output loss after a bank crisis will amount to $10 \%$, while it will be about 2.5 after a currency crisis. The recent financial crisis is likely to have impacted the global economy significantly. Although the IMF reported that the rate of GDP growth 
was about $5 \%$ since 2004 in the world, this growth rate declined to $3.1 \%$ at the end of 2008 . This was seen as the lowest rate for the period from 2003-2008. In 2009, IMF equally reported a $1.5 \%$ growth rate of GDP. The influence of this episode of crisis is however different from previous recessions which is due to the rapid globalization of the financial market and the global economy such that the effect of the crisis spread throughout emerging countries (Paul \& Ichinois, 2014).

Although over the years, this economic bloc has been known for their tremendous potential for growth, they are recently in adverse economic and political situation. These have been greatly influenced by the fall in the price of commodity globally. This is also due to the fact that these economies depend on export led growth. India however rely less on export for growth thus, it is less susceptible to volatility in the market and as a net importer of commodities and crude, it has greatly gained hence its growth potential remains strong. Nevertheless, India's GDP of $\$ 5,238$ is said to be the lowest compared to other members of the bloc. The quality of life in India also is behind that of other members but with the initiation of economic reforms by the president, there has been increase in foreign Direct Investment and improvement in its economic competitiveness.

Narayanamurthy (2011) noted that some African economies have been a destination for most foreign direct investment (FDI) in the last decade. Multinational cooperations moved their activities to China so as to benefit from the cheaper cost of labour and the large market size. In that ranking, Russia, Brazil, India and South Africa were ranked eight, nine, thirteen and thirty-five, respectively, in the world. The inflow of FDI in the last five years into Brazil, India and South Africa has been small and almost constant.

The BRICS economies, despite their huge currentaccount and foreign reserves, are immune to external threat. Many of the investors from US withdrew their investments in the stock market of these countries and this shrunk their stock market index. Therefore, this study focused on examining the impact of financial crisis on some African. African economies were recognized as the growth poles. They are heterogonous in nature and they have great pool of both human and physical resources and a fast rising share in the global Gross Domestic Product (GDP). The occurrence of the financial crisis proved these economies as capable of replacing US as an engine of global economic growth. The impact of the crisis on these economies was not as severe as that experienced by many developing and developed economies. Upon this background, this paper seeks to examine empirically the extent of the impact of the financial crisis on the economic growth of these economies as well as its impact on the FDI in these countries.

The rest of this paper is structured as follows: section two focused on the theoretical and empirical literature; section three deals with the methodology and in section four the empirical results are presented; finally, section five handles the conclusion of the study and policy recommendations.

\section{RELEVANT LITERATURE}

This section discusses the various underpinning theories for the study and as well captures the empirical literature. The two major theories examined for this study are Growth theory and Investment theory. The neoclassical growth model is one of the economic models which outline how the steady growth rate of an economy can be achieved. This theory posits that there are three main drivers of economic growth. These drivers include capital, labour and technology. It states that when the amount of capital and labour are varied in the production function, a steady state can be achieved. Based on this theory, change in technology has greater impact on the economy; thus, economic growth cannot increase without improvement in technology.

In essence, the neoclassical growth model suggests that capital accumulation in an economy, and how this is used by people, is crucial for growth of the economy. That is, the capital/labour relationship in an economy determines the growth or output of that economy. Based on the theory, technology is said to be labouraugmenting, meaning that it enhances or increases the productivity of labour. Therefore, to measure the growth of an economy, the neoclassical growth theory uses the production function, which expresses equilibrium and growth of the economy $(\mathrm{Y})$ as a function of capital $(\mathrm{K})$, labour $(\mathrm{L})$ and technology $(\mathrm{A})$. This can be written mathematically as $Y=A F(K, L)$. As stated earlier, technology is labour-augmenting; hence, this function can be rewritten as: $Y=F(K, A L)$, where $Y$ is the Gross Domestic Product, $\mathrm{K}$ is the share of capital, $\mathrm{L}$ is labour and $A$ is rate of technology.

On the side of investment, one of the theories of FDI examined emanates from the work done by 
Dunning in 1977 and 1979 which stands as the most comprehensive theories of FDI. This theory is the amalgamation of the internationalisation and the oligopolistic theories (the imperfect market-based theories) and the addition of the dimension of location theory in explaining the reason for a firm to open a subsidiary in a foreign country. The location theory made effort in addressing the issue of who produces what goods or services in which location and the reason for this venture. Other researchers found this theory very useful as they often apply it in an attempt to gain knowledge about the factors influencing the location of multinational corporations such as the economic fundamentals, host country policies, firm's strategy and agglomeration economies.

Given the above background, the theory postulated by Dunning (1993) was known as the eclectic paradigm. This theory suggests that the position of a country's direct investment in other countries is influenced by three factors, which include ownership advantage (O), locational advantage (L), and internalising advantage (I). Hence, this theory is known as the OLI theory of FDI. Accordingly, a firm would embark on FDI if it meets the following requirements: ownership advantage alongside other firms, the profitability of internalizing this advantage other than using the market to transfer them to foreign firms and if it has some location advantage in the use of the firm's ownership advantage in a foreign land (L). Ownership advantage or firm's specific advantage is the asset or right accessible to a firm which other foreign firms do not have. This leads to low cost of production for the firm and it enables it to compete favourably with foreign firms. Location advantage, on the other hand, is based on the endowment peculiar to specific location that cannot be transferred across boundaries. This determines the direction of the flow of multinational corporations' activities; that is, which country will be the host to Multinational Corporations (MNCs) and the internalising advantage explain if the firm with ownership advantage considers it profitable to use it within rather than selling it to foreign firms.

Dunning (1980) is of the view that these three determinants of FDI and MNCs are supportive of each other so that FDI is possible by a firm only when it possesses these advantages, meaning that FDI can only take place if and only if these three conditions are met. If a firm has both ownership advantage and internalisation gain but does not have location advantage, it will engage in increased production domestically and export product(s) to other countries; nevertheless, if internalisation gain is not in place, then it will be more profitable for the firm to license its ownership advantage to foreign firms.

Although, the eclectic theory contributes to existing literature on FDI by putting different theories together to show a group of factors influencing the activities of MNCs as well as obtaining satisfactory results by testing the theory empirically, the theory was criticised on the ground that it includes too many variables that makes it lose operational practicality. Dunning, however, admitted this fact stating that it is the resultant effect of trying to combine several motivations for FDI into a single comprehensive theory.

The criticism led to the Investment Development Cycle or Path (IDP), which states that there is a link between the level of economic development of a country captured in the per capita GDP and the international investment position. This theory, unlike the eclectic paradigm, admits that a government can affect the economic conditions of the country through its policies, which will as well affect the flow of FDI and ownership advantage of local firms. Thus, it introduced a new notion of dynamic approach to the eclectic theory

Many studies have been done related to the impact of financial crisis on the economic growth and the level of investment in some countries. Countries which suffered from financial crisis have been affected in diverse ways. UNCTAD (1998) noted that countries such as South Korea, Indonesia, the Philippines, Malaysia and Thailand, which suffered severely from the Asian financial and currency crisis, which broke out in 1997 in Thailand, recorded a negative portfolio and net private bank lending in 1997 . The region experienced a fall in the flow of private external capital. UNCTAD equally noted that the inflow of FDI into the Asian and pacific region after the crisis decreased by US\$38 million.

Furceri and Mourougane (2009) examined the effect of financial crises on GDP. The panel model is such that the GDP growth is a function of its history and dummy variables linked to the crises. They found that, on average, GDP will fall by $1.5 \%$ to $2.4 \%$ after a crisis. The decrease extends over five years. Thangavelu et al. (2009) examined some Asian countries by analysing FDI, Growth and the Asian financial crisis, and they observed that though the South- East Asian countries as well as the East Asian countries were recuperating with strong growth output from the crisis, which was 
majorly led by the growth in export. However, they found that the recovery came along with a fall in the inflow of FDI, rising government deficits and growing rates of unemployment in the South East.

In the same vein, Barro (2001) investigated economic growth in five East Asian countries before and after the financial crisis of 1997- 1998 and found that real GDP contracted more severely than the previous periods. The study found that, compared to five other Asian countries, which were less affected, the real GDP of Malaysia, the Philippines, South Korea, Thailand and Indonesia contracted more. It was also discovered that there was a sharp fall in investment ratio in these countries but the fall was not that much in the less affected countries. The study found that growth was recovering during the period 1999-2000 but it was not certain if this was going to be permanent. However, the investment ratio was not rebounding significantly, which, according to the author, was a sign that the impact of the crisis on these countries was long lasting and adverse. The conclusion was reinforced, having observed that the stock market prices failed to return to the pre-crisis values in the affected countries. Results from the panel analysis of broad group of economies indicate that both bank and currency crisis reduced growth by 2 percent over the period of 5years relative to 3 percent for the period 1997/1998 in the East Asian crisis-affected countries.

Jadhav (2012) examined the role of economic, political and institutional factors in attracting FDI in BRICS by employing panel data for the period 20002009 and a multiple regression model to achieve the set goal. The study used variables such as market size, trade openness, inflation rate as macroeconomic stability, political stability, besides corruption and Rule of law. The author found that economic variables such as real GDP, which measure the market size, trade openness, natural resource availability, voice, rule of law and accountability were statistically significant in influencing FDI. The sign of the Real GDP was found to be positive, implying that FDI in BRICS is marketseeking while the negative relationship between natural resource availability found indicates that FDI in BRICS is not resource-seeking. Trade openness was found to have a positive relationship with FDI and it statistically significant. Gaurav (2015) conducted a panel study of FDI and economic growth in the BRICS economies for the period of 1989-2012. The study employed the method of cointegration and causality and it was found that FDI and economic growth have a long run relationship at the panel level, which implies that they are cointegrated. It was equally discovered that there is long run causality from FDI to economic growth in the BRICS economies.

Becker and Mauro (2006) examined the occurrence, length and costs of different shocks. The results show that financial shocks and macro-economic relations are costly in relation to annual losses on GDP per capita for developing countries. Also, trade-related shocks and interest rates are more damaging for emerging countries. Ksantini \& Boujelbène (2014) examined the effect of financial crisis on growth and investment for twenty-five countries using a dynamic panel model for the period 1998-2009. This study, unlike others, integrated a new measure of financial crisis instead of the use of dummy. The results obtained showed that financial crisis has a negative and significant impact on country growth of GDP and investment.

Bordo et al. (2001) assesed the development of the length and depth of the diverse kinds of crises. This study covered the period 1980 to 1997 . It is observed that the impact of crisis on duration and depth varies according to the period studied as well as the type of crisis and the number of countries. The impact of banking crisis compared with currency crisis is more in terms of depth and duration. They found that these financial crises impact significantly more on GDP than other crises. The results indicate that financial crisis caused GDP to fall by $5 \%$ to $10 \%$ and this fall last for $2-$ 3years. Cecchetti, et al. (2009) studied the output cost of 40 systemic banking crisis since 1980. They establish that only $20 \%$ of crisis has a permanent impact on the level of GDP. Nevertheless, it was noted that most systematic banking crises coincided with a marked decrease in growth and that this decline takes several years to recover their previous levels. According to Aw \& Tang (2010), the level of foreign Direct Investment inflow in Malaysia is majorly determined by the level of corruption, the rate of inflation, interest rate, openness and the joining of China into the WTO. The study equally found that the FDI is correlated with these determinants. All these studies converge towards a conclusion: GDP growth will be affected over a long period.

\section{DATA AND METHODOLGY}

Annual time series data over the period 1994 to 2014 are employed from the BRICS countries. The data were obtained from the world development indicator data base of the World Bank. This section captures the model specification, a priori expectation 
and the estimation technique. A Panel Vector Error Correction (PVEC) model is used to examine the relationship between GDP or FDI and the various macroeconomic variables used as independent variables in the two models estimated. The systematic process followed includes the test for stationarity of variables, the Pedroni Residual cointegration test and the PVEC model. The last test to be performed is the Wald coefficient diagnostic test for each model to test the causality from independent variables to dependent variable in the models estimated.

\subsection{Panel Unit Root Test}

This study applies the Levin et al. (2002) and the IPS (Im et al., 2003) panel unit root tests to series to determine if the variables are stationary or not. Both tests allow for heterogeneity of the intercept among members of the panel, but the IPS test, also known as the heterogeneity panel unit root test, equally allows for heterogeneity in the slope coefficients. The null hypothesis is that a series has a unit root, which implies that a series is non-stationary. Decision is made at the $5 \%$ significant level and if the p-value of the statistic is more than the $5 \%$ significance level, we fail to reject the null hypothesis, but if the p-value is less than $5 \%$ significance level, we reject the null hypothesis and accept the alternative hypothesis and conclude that the series is stationary.

\subsection{Panel Cointegration Test}

There are two basic tests for panel cointegration analysis. These include residual-based test for cointegration and maximum-likelihood-based test for cointegtarion. This current study follows the maximumlikelihood-based test for cointegration. Thus, we apply the Fisher - Johansen type of panel cointegration proposed by Maddala and Wu (1999) to determine the long run association among the variables. This test of cointegration is an extension of the Johansen's (1988) cointegration test for nonstationary panel data. The motivation for this test is that it does not assume just one cointegrating equation as is the case with the residual-based test. Thus, it can identify the number of cointegrating vectors. Aside from determining the number of cointegrating equations, this test is also independent in choosing the variable that is used for normalizing the cointegrating vector. Paramati et al. (2016) noted that this test for cointegration accounts for individual effects in the vector autoregressive models, but not the individual linear trends.
In general, the panel cointegration test begins by estimating the vector error correction model below:

$$
\begin{gathered}
\Delta y_{i t}=\alpha_{i} \beta_{i} y_{i, t-1}+\sum_{j=1}^{p i-1} \Gamma_{i j} \Delta \gamma_{i, t-j}+Z_{i} d_{t}+\varepsilon_{i t} \\
t=1, \ldots, T, i=1, \ldots, N
\end{gathered}
$$

where $t$ and $i$ are indexes of time dimension and cross section, respectively, while $\varepsilon_{i t}$ is an error term assumed to be distributed independently; ie., $\varepsilon_{i t} \sim N K\left(0, \Omega_{i}\right)$. The process $y_{i t}$ of $\mathrm{K}$-dimension is at most integrated of order one; that is, I(1) with a cointegrating rank of $0 \leq r_{i} \geq K$. The unknown $\left(K \times r_{i}\right)$ and $\alpha_{i}$ and $\beta_{i}$ are the loading and the cointegrating matrices, respectively, and they have full column rank. $p i-1$, is the lag order of the vector error correction (VEC) process and is either different across the crosssection or controlled to be constant.

The short run dynamics of the process is represented by the unknown coefficient matrices denoted as $\Gamma_{i j}, i=1, \ldots, N ; j=1, \ldots, p i-1$, while the long run dynamics are represented as $\Pi_{i}=\alpha_{i} \beta_{i}, i=1, \ldots, N$. $Z_{i}$ is the unknown parameter vector of the deterministic terms, while the $d_{t}$ vector contains the deterministic terms.

\subsection{Vector Error Correction Model}

VECM is a restricted VAR that is used with nonstationary series that are identified to be cointegrated. This model has cointegration relations built into the specification such that it restricts the long run behavior of the endogenous variables to converge to their long run relationships, while it allows for shortrun adjustment dynamics. According to Hassan (2003), VECM defines how the system is adjusting in each time period towards its long run equilibrium state. The cointegration term is called the error correction term and as concluded by Hassan (2003), the coefficients of the error-correction term indicate the proportion of the long-run disequilibrium in the dependent variables corrected in each period. Following the maximumlilkelihood approach of panel conitegration, the long run and short run dynamics are generated by estimaiting the above stated VEC model.

\subsection{Model Specification}

\subsubsection{Growth Model}

This study adopts the multivariate growth models of Dritsakis (2004) and Dritsakis et al. (2006) where 
growth is modelled as a function of international tourism earnings and real exchange rate, and GDP per capita is a function of the ratio of export to GDP, the ratio of gross capita formation to GDP and the ratio of foreign direct investment to GDP. However, to capture the effect of financial crisis on growth, which is the main focus of this study, the adopted model is modified with inclusion of a dummy variable representing the crisis. Also, trade is used as a proxy of openness of the economies. The growth function is written as follows:

GDPPC $=f($ GFCF, REER, TRADE, FDI, DUM $)$

This implies that Gross Domestic Product Per capita (GDPPC) is a function of Investment (GFCF), Real effective exchange rate (REER), trade, foreign direct investment (FDI) and the dummy representing financial crisis (FC). This econometric model can be written in log form as follows:

LNGDPPC $_{i, t}=\beta_{0}+\beta_{1}$ LNGFCF $_{i, t}+\beta_{2}$ LNREER $_{i, t}+$ $\beta_{3}$ LNTRADEi,t $+\beta_{4}$ LNFDI $+\beta_{5}$ DUM $+e_{i, t}$

where $\mathrm{i}$ and $\mathrm{t}$ represent countries and time, respectively, and $\beta_{0}$ is the intercept of the equation, $\beta_{1}$ is the parameter of GFCF, $\beta_{2}$ is the parameter of REER, $\beta_{3}$ is the parameter of TRADE, $\beta 4$ is the parameter of FDI, $\beta_{5}$ is the parameter of DUM, and e is the error term. The a priori expectation is that both GFCF, TRADE and FDI are postively related to GDPPC, while REER and DUM are expected to influence GDPPC negatively.

\subsubsection{FDI Model}

The Jadhav (2012) model for FDI is adopted, but it's modified to suit this current study. Therefore, the foreign direct investment is modelled as a function of Gross Domestic Product per capita (GDPPC), real exchange rate (REER), TRADE and a dummy (DUM) representing financial crisis - with the following equation:

FDI $=f($ GDPPC, REER, TRADE, DUM)

The econometric model is specified as follows:

LNFDI $_{\mathrm{i}, \mathrm{t}}=\beta 0+\beta_{1}$ LNGDPPC $_{\mathrm{i}, \mathrm{t}}+\beta_{2}$ LNREER $_{\mathrm{i}, \mathrm{t}}+$ $\beta_{3}$ LNTRADEi,t $+\beta_{4}$ DUM $+e_{i, t}$

where $\mathrm{i}$ and $\mathrm{t}$ represent countries and time respectively. $\beta 0$ is the intercept for equation, $\beta_{1}$ is the parameter of GDPPC, $\beta_{2}$ is the parameter of REER, $\beta_{3}$ is the parameter of TRADE, $\beta 4$ is the parameter of DUM and $\mathrm{e}$ is the error term.
The a priori expectation is that both GDPPC and TRADE are positively related to FDI, while REER and DUM are negatively related to FDI. The variables are transformed into logs so as to explain the estimates of parameters as elasticities.

\section{PRESENTATION OF RESULTS}

\subsection{Test of Unit Root}

Tables $\mathbf{1 a}$ and $\mathbf{1 b}$ below represent the results of the unit root tests performed for the model 1 (growth model) and model 2 (FDI model). The unit root tests performed are the Levin et al. (2002) and IPS (Im et al., 2003). The results indicate that variables are only stationary after first difference. Thus, it is concluded that the series are all integrated of order one. With stationarity achieved at first difference, the cointegration test can be performed.

\subsection{Cointegration Test Results}

From the stationarity test performed, the variables are all integrated of order one [I (1)]. This study employed the Fisher- Johansen panel cointegration test and the results for both models 1 and 2 are presented in Table $\mathbf{2} \mathbf{a}$ and $\mathbf{2} \mathbf{b}$, respectively, as shown below:

In Table 2a below, both Trace test and Max-eigen test statistics indicate that there are at most four cointegrating equations at $5 \%$ significance level for the growth model, and from Table $\mathbf{2 b}$, Trace test identifies at most four cointegrating equations while max-eigen test found at most three cointegrating equations for the FDI model. However, only results of one cointegrating equation is presented here for both models to avoid complexity as suggested by Brooks (2014). From these cointegration results, this study, therefore, rejects the null hypothesis of no cointegration among the variables employed in the two models and accept the alternative hypothesis of at most four cointegrating equations in each model.

\subsection{Vector Error Correction Model}

From the Cointegration test performed, it is observed that there is a long run relationship among the variables. Hence, the panel VECM is estimated, which provides both the long run and short run results. The long run and short run results are presented in Table $\mathbf{3 a}$ and $\mathbf{3 b}$, respectively, for model 1 . 
Table 1a: Panel Unit Root Test for Growth Model

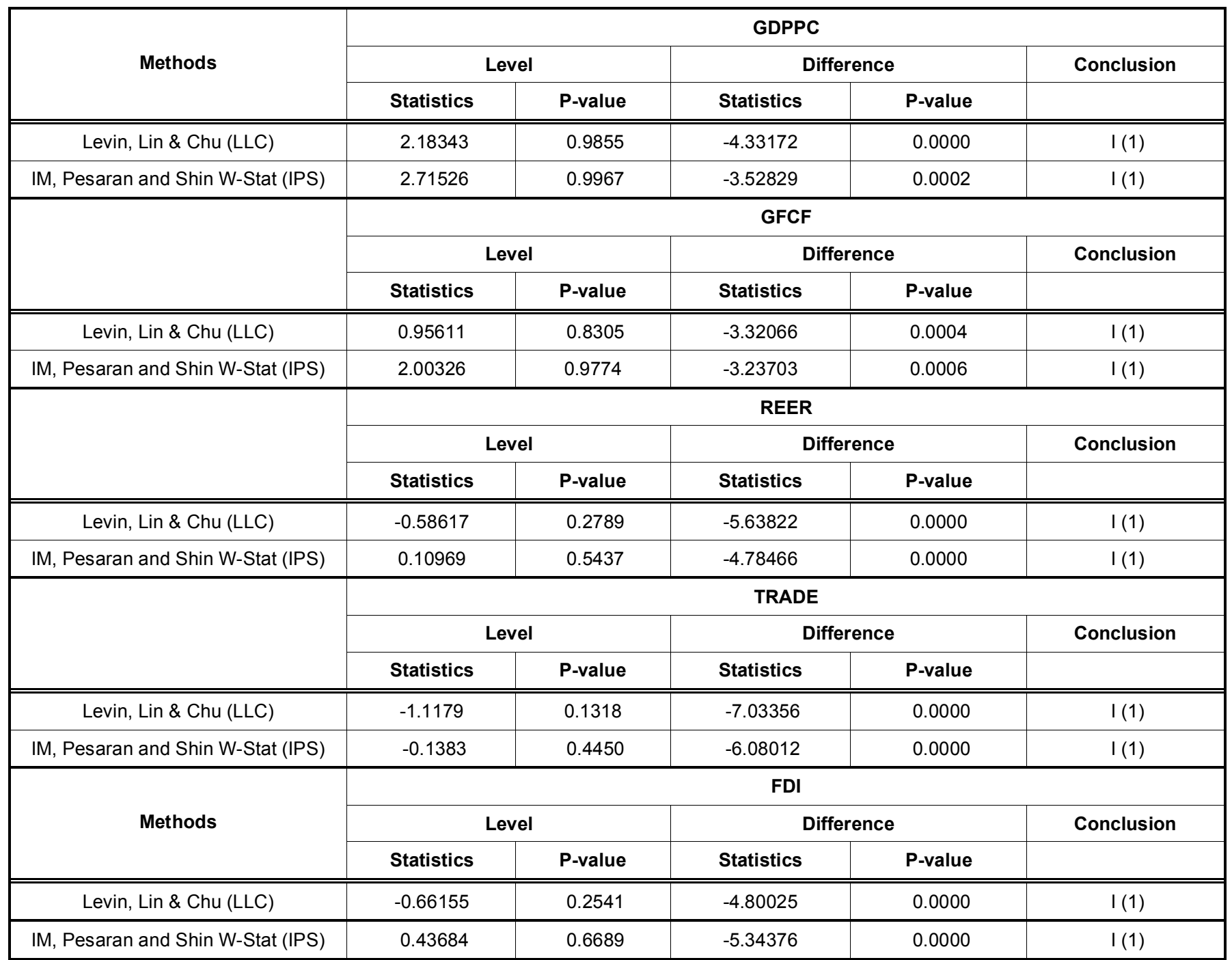

In the Table 1a above, GDPPC is the Gross Domestic Product Per Capita, GFCF is Gross Fixed Capital Formation, REER captures the Real Exchange Rate, TRADE is the trade variable while FDI is Foreign Direct Investment.

Table 1b: Panel Unit Root Test for FDI Model

\begin{tabular}{|c|c|c|c|c|c|}
\hline \multirow{3}{*}{ Methods } & \multicolumn{5}{|c|}{ FDI } \\
\hline & \multicolumn{2}{|c|}{ Level } & \multicolumn{2}{|c|}{ Difference } & Conclusion \\
\hline & Statistics & P-value & Statistics & P-value & \\
\hline Levin, Lin \& Chu (LLC) & -0.6616 & 0.2541 & -4.8003 & 0.0000 & I (1) \\
\hline \multirow[t]{2}{*}{ IM, Pesaran and Shin W-Stat (IPS) } & 0.43684 & 0.6689 & -5.3438 & 0.0000 & $I(1)$ \\
\hline & Statistics & P-value & Statistics & P-value & \\
\hline Levin, Lin \& Chu (LLC) & 2.18343 & 0.9855 & -4.3317 & 0.0000 & $I(1)$ \\
\hline IM, Pesaran and Shin W-Stat (IPS) & 2.71526 & 0.9967 & -3.5283 & 0.0002 & \\
\hline
\end{tabular}


(Table 1b). Continued.

\begin{tabular}{|c|c|c|c|c|c|}
\hline & \multicolumn{5}{|c|}{ GFCF } \\
\hline & \multicolumn{2}{|c|}{ Level } & \multicolumn{2}{|c|}{ Difference } & \multirow[t]{2}{*}{ Conclusion } \\
\hline & Statistics & P-value & Statistics & P-value & \\
\hline Levin, Lin \& Chu (LLC) & -0.8022 & 0.2112 & -6.5995 & 0.0000 & $I(1)$ \\
\hline \multirow[t]{2}{*}{ IM, Pesaran and Shin W-Stat (IPS) } & -0.07907 & 0.4685 & -5.24069 & 0.0000 & I (1) \\
\hline & Statistics & P-value & Statistics & P-value & \\
\hline Levin, Lin \& Chu (LLC) & -0.5862 & 0.2789 & -5.6382 & 0.0000 & \\
\hline \multirow[t]{2}{*}{ IM, Pesaran and Shin W-Stat (IPS) } & 0.10969 & 0.5437 & -4.7847 & 0.0000 & \\
\hline & \multicolumn{5}{|c|}{ TRADE } \\
\hline Levin, Lin \& Chu (LLC) & -1.1179 & 0.1318 & -7.0336 & 0.0000 & I (1) \\
\hline IM, Pesaran and Shin W-Stat (IPS) & -0.13833 & 0.4450 & -6.08012 & 0.0000 & I (1) \\
\hline
\end{tabular}

From Table 1b above, FDI is Foreign Direct Investment, GDPPC is the Gross Domestic Product Per Capita, GFCF is Gross Fixed Capital Formation, REER captures the Real Exchange Rate, while TRADE is the trade variable.

Table 2a: Fisher-Johansen Panel Cointegration Test for Model 1 (Growth Model)

\begin{tabular}{|c|c|c|c|c|}
\hline \multicolumn{2}{|c|}{ Unrestricted Cointegration Rank Test (Trace and Maximum Eigenvalue) } \\
\hline Hypothesized & \multicolumn{2}{|c|}{ Fisher Stat. ${ }^{*}$} & \multicolumn{3}{c|}{ Fisher Stat. ${ }^{*}$} \\
\hline No. of CE(s) & (from trace test) & Prob. & (from max-eigen test) & 127.7 \\
\hline \hline None & 242.7 & 0.0000 & 91.89 & 0.0000 \\
\hline At most 1 & 146.4 & 0.0000 & 42.59 & 0.0000 \\
\hline At most 2 & 74.06 & 0.0000 & 25.64 & 0.0000 \\
\hline At most 3 & 42.03 & 0.0000 & 24.89 & 0.0043 \\
\hline At most 4 & 25.44 & 0.2381 & 12.75 & 0.0056 \\
\hline At most 5 & 12.75 & & \\
\hline
\end{tabular}

Table 2b: Fisher-Johansen Panel Cointegration Test for Model 2 (FDI Model)

\begin{tabular}{|c|c|c|c|c|}
\hline \multicolumn{5}{|c|}{ Unrestricted Cointegration Rank Test (Trace and Maximum Eigenvalue) } \\
\hline None & 236.9 & 0.0000 & 143.0 & 0.0000 \\
\hline At most 1 & 146.7 & 0.0000 & 87.33 & 0.0000 \\
\hline At most 2 & 76.70 & 0.0000 & 51.14 & 0.0000 \\
\hline At most 5 & 11.49 & 0.3210 & 11.49 & 0.3210 \\
\hline
\end{tabular}

These results above show that GDPPC is positively influenced by GFCF, TRADE and FDI. This means that an increase in GFCF, TRADE and FDI would cause
GDPPC to increase. The coefficients indicate that a $1 \%$ increase in GFCF, TRADE, FDI will cause GDPPC to increase by $1.79 \%, 0.45 \%$ and $0.03 \%$, respectively. On 
Table 3a: Long Run Cointegrating Equation of Model 1

\begin{tabular}{|c|c|c|c|}
\hline Variables & Coefficient & Std. Error & t-Statistic \\
\hline \hline LNGDPPC(-1) & 1 & & -5.58753 \\
\hline LNGFCF(-1) & -1.793601 & -0.321 & 3.46428 \\
\hline LNREER(-1) & 1.591588 & -0.19032 & -2.36898 \\
\hline LNTRADE(-1) & -0.450864 & -0.06352 & -0.47299 \\
\hline LNFDI(-1) & -0.030046 & -0.25034 & -0.10819 \\
\hline DUM & 0.027085 & & \\
\hline C & -0.409977 & & \\
\hline
\end{tabular}

From Table 3a, GDPPC stands for (Gross Domestic Product Per Capita), GFCF (Gross Fixed Capital Formation), REER is the Real exchange rate, TRADE is the trade variable, FDI is (Foreign Direct Investment) while DUM is a dummy which captures financial crisis.

From the above Table $3 a$, the long run equation can be specified as

LNGDPPC $=0.41+1.79$ LNGFCF -1.59 LNREER + 0.45TRADE + 0.03LNFDI - 0.03DUM

Table 3b: The Short Run Results (Error Correction Model) for Model 1

\begin{tabular}{|c|c|c|c|}
\hline Variables & Coefficient & Std. Error & t-Statistics \\
\hline \hline ECT & -0.55027 & -0.15489 & -3.55262 \\
\hline$D($ LNGDPPC(-1)) & -0.26718 & 0.14124 & -1.89161 \\
\hline$D($ LNGFCF(-1)) & -2.71497 & 1.85196 & -1.466 \\
\hline D(LNREER(-1)) & -0.24716 & 1.39241 & -0.17751 \\
\hline$D($ LNTRADE(-1)) & -0.39348 & 1.36962 & -0.28729 \\
\hline D(LNFDI(-1)) & -0.29817 & 0.15356 & -1.94175 \\
\hline
\end{tabular}

Table 3c: Panel VEC Granger Causality/Block Exogeneity Wald Tests for Model 1

\begin{tabular}{|c|c|c|c|}
\hline \multicolumn{4}{|c|}{ Panel VEC Granger Causality/Block Exogeneity Wald Tests } \\
\hline \multicolumn{3}{|c|}{ Dependent variable: D(LNGGDPPC) } & \multirow[b]{2}{*}{ Prob. } \\
\hline NULL HYPOTHESIS & Chi-sq & df & \\
\hline D(LNGFCF) does not granger-cause D(LNGGDPPC) & 4.485909 & 2 & 0.1061 \\
\hline D(LNREER) ) does not granger-cause D(LNGGDPPC & 2.549593 & 2 & 0.2795 \\
\hline All variables granger-cause $\mathrm{D}($ LNGGDPPC & 15.85656 & 8 & 0.0445 \\
\hline
\end{tabular}

the other hand, the coefficients of REER and financial crisis (DUM) is negative which imply that increase in REER and DUM will cause GDPPC to fall by $1.59 \%$ and $0.03 \%$, respectively. The t-Statistics of the variables GFCF and TRADE and REER showed that they are statistically significant while that of FDI and DUM are statistically insignificant.

From Table $\mathbf{3 b}$, the error correction term (ECT) is approximately -0.550 . The sign of the coefficient is negative as expected and it is statistically significant given the t-statistic of -3.553 . This coefficient indicates the speed of adjustment to equilibrium when there is any disequilibrium in the economy. This implies that disequilibrium in the previous period is adjusted at the speed of $55.0 \%$ each year. The coefficient of this ECT also indicates that there is long run causality running from the independent variables to the dependent variable (GDPPC).

This test indicates that there is no causality running from DLNGFCF, DLNREER, and DLNTRADE to DLNGDPPC since the p-values are more than $5 \%$ significance level; but causality is observed to run from 
DLNFDI to DLNGDPPC given that the p-value is less than $5 \%$. These results also show that these variables collectively granger-cause growth at the $5 \%$ significance level.

Also, the cointegrating test performed for model 2 (FDI model) also showed that there is a long run relationship among the variables. Hence, the panel VECM is estimated which provides both the long run and short run results. The long run and short run results are presented in Table $\mathbf{4 a}$ and $\mathbf{4 b}$, respectively, for model 2.
The results indicate that FDI has a significant positive relationship with both GDPPC and GFCF in BRICS while it has a negative significant relationship with real effective exchange rate and trade. This shows that if GDPPC and GFCF increase by $1 \%$, FDI will increase by $0.489 \%$ and $4.072 \%$, respectively, while a $1 \%$ increase in real exchange rate and trade will depress FDI by $3.818 \%$ and $1.989 \%$. Also observed from the result is that FDI has a negative significant relationship with financial crisis (DUM). Since this relationship is significant, a $1 \%$ increase in the financial

Table 4a: Long-Run Cointegrating Equation of the FDI Model (Model 2)

\begin{tabular}{|c|c|c|}
\hline Variables & Coefficient & Std. Error \\
\hline \hline LNFDI(-1) & 1.000000 & -0.16785 \\
\hline LNGDPPC(-1) & -0.488938 & -0.52013 \\
\hline LNGFCF(-1) & -4.07185 & -0.85522 \\
\hline LNREER(-1) & 3.817599 & -0.30803 \\
\hline LNTRADE(-1) & 1.989653 & -0.43098 \\
\hline DUM & 1.121415 & -4.82847 \\
\hline C & -30.91252 & -2.60203 \\
\hline
\end{tabular}

From Table 4a, FDI is (Foreign Direct Investment), GDPPC stands for (Gross Domestic Product Per Capita), GFCF (Gross Fixed Capital Formation), REER is the Real exchange rate, TRADE is the trade variable, while DUM is a dummy which captures financial crisis.

The long run equation is specified as follows:

LNFDI = 30.913 + 0.489LNGDPPC + 4.072LNGFCF - 3.818LNREER - 1.989LNTRADE - 1.121DUM.

Table 4b: Short Run Results (Error Correction Model) for Model 2

\begin{tabular}{|c|c|c|c|}
\hline Variables & Coefficient & Std. Error & t-Statistics \\
\hline \hline ECT & -0.247595 & -0.07143 & -3.4662 \\
\hline $\mathrm{D}($ LNFDI(-1)) & -0.446112 & 0.10991 & -4.059 \\
\hline $\mathrm{D}(\mathrm{LNGDPPC}(-1))$ & 1.676353 & 0.69604 & 2.40841 \\
\hline $\mathrm{D}(\mathrm{LNGFCF}(-1))$ & -0.062118 & 1.1812 & -0.0526 \\
\hline $\mathrm{D}(\mathrm{LNREER}(-1))$ & -1.515961 & 1.14337 & -1.3259 \\
\hline $\mathrm{D}(\mathrm{LNTRADE}(-1))$ & 0.737730 & 0.81584 & 0.90426 \\
\hline $\mathrm{D}(\mathrm{DUMM}(-1))$ & 0.265933 & 0.19602 & 1.35668 \\
\hline
\end{tabular}

Table 4c: Panel VEC Granger Causality/Block Exogeneity Wald Test for Model 2

\begin{tabular}{|c|c|c|c|}
\hline \multicolumn{4}{|c|}{ Panel VEC Granger Causality/Block Exogeneity Wald Test } \\
\hline Excluded & Chi-sq & df & Prob. \\
\hline $\mathrm{D}($ LNGDPPC) does not granger-cause $\mathrm{D}(\mathrm{LNFDI})$ & 10.85066 & 2 & 0.0044 \\
\hline $\mathrm{D}($ LNGFCF) does not granger-cause $\mathrm{D}$ (LNFDI) & 1.481617 & 2 & 0.4767 \\
\hline $\mathrm{D}($ LNREER) does not granger-cause D(LNFDI) & 2.274415 & 2 & 0.3207 \\
\hline $\mathrm{D}($ LNTRADE) does not granger-cause $\mathrm{D}($ LNFDI) & 0.817689 & 2 & 0.6644 \\
\hline All does not granger-cause D(LNFDI) & 30.10766 & 10 & 0.0008 \\
\hline
\end{tabular}


crisis will cause FDI to fall by $1.121 \%$. The t-statistics of $-2.91298,-7.82847,4.4639,6.45921$, and -2.60203 for the variables LNGDPPC, LNGFCF, LNREER, LNREER, LNTRADE and DUM indicate that the variables are significant in explaining the inflow of FDI in the countries of BRICS.

From Table $\mathbf{4 b}$, the error correction term (ECT) is approximately -0.248 . The sign of the coefficient is negative as expected, and it is statistically significant given the t-statistic of -3.46618 . This coefficient indicates the speed of adjustment to equilibrium when there is any disequilibrium in the economy. This implies that disequilibrium is corrected at the speed of $24.8 \%$ to equilibrium yearly. The coefficient of this ECT also indicates that there is long run causality running from the independent variables to the dependent variable (FDI).

From this test we observed that there is causality running from DLNGDPPC and DUM to DLNFDI since their $p$-values are less than $5 \%$ significant level, while there is no causality running from LNGFCF,LNREER AND DLNTRADE to DLNFDI. However, the independent variables jointly granger causes DLNFDI given the $p$-value less than $5 \%$ significant level.

\section{CONCLUSION}

This study investigates the effect of financial crisis on both economic growth and FDI in the BRICS countries. The study estimated two distinct models: model 1 (growth model) and model 2 (FDI model) as specified above. The study used panel data which were sourced from World Bank data-base. The panel Vector Error Correction technique was employed for this analysis. Upon the discovery of cointegration among the variables in the two models, the VECM was estimated which provided both long run and short run results.

From the growth model, it was observed that Gross Domestic Product Per Capita is positively influenced by Gross Fixed Capital Formation, TRADE and Foreign Direct Investment. While both Gross Fixed Capital Formation and TRADE are statistically significant, Foreign Direct Investment is not significant. Gross Domestic Product Per Capita has negative significant relationship with Real Exchange Rate but it has a negative insignificant relationship with financial crisis; that is, although the effect of financial crisis is negative as expected, it's insignificant in influencing the growth of the BRICS countries. On the other hand, the Foreign Direct Investment model showed that FDI has a significant positive relationship with both Gross Domestic Product Per Capita and Gross Fixed Capital Formation in BRICS while it has a negative significant relationship with real effective exchange rate and trade. Also observed from the result is that FDI has a negative significant relationship with financial crisis. Since this relationship is significant, a $1 \%$ increase in the financial crisis will cause FDI to fall by $1.121 \%$ as shown above.

Given these results, it is concluded that financial crisis has a negative relationship with both economic growth (GDPPC) and foreign Direct Investment (FDI) in the BRICS economies. Though the effect of financial crisis on growth is insignificant, it is significant on FDI which could be the reason FDI did not impact significantly on growth as observed from results of the growth model.

The policy recommendations for the study are revealing. It is important for the governments of the BRICS countries to strive for more openness of the economy so as to promote both growth and inflow of FDI in these countries. It is also recommended that there should be a drive to encourage more gross fixed capital formation in order to promote both growth and FDI. However, the exchange rates must be adjusted so that foreign investors can be motivated to invest in these countries. Finally, the presence of financial crisis impacts negatively on both growth and FDI in these countries. Thus, the governments must ensure that measures are put in place to combat this adverse influence of financial crisis in the BRICS countries.

\section{REFERENCES}

Aw, T.Y. \& Tang, T.C., (2010). The determinants of inward foreign direct investment: The case of Malaysia. International Journal of Business and Society, 11(1), p.59.

Barro, R.J., (2001). Economic growth in East Asia before and after the financial crisis (No. w8330). National Bureau of Economic Research.

https://doi.org/10.3386/w8330

Becker, T. \& Mauro. P., (2006). "Output Drops and the Shocks that Matter," IMF Working Papers, 06/172, 1-43. https://doi.org/10.5089/9781451864328.001

Bordo, M. D., Eichengreen, B., Klingbiel, D., \& Martinez-Peria. M.S., (2001). "Is the crisis problem growing more severe?," Economic Policy, 32, 53-82 https://doi.org/10.1111/1468-0327.00070

Cecchetti, S. G., Kohler, M. \& Upper, C., (2009). "Financial Crises and Economic Activity," NBER Working Papers, 15379. https://doi.org/10.3386/w15379

Chris, B., (2008). Introductory econometrics for finance. Cambrige, Cambrige University.

Dritsakis, N., (2004). Tourism as a long-run economic growth factor: an empirical investigation for Greece using causality analysis. Tourism Economics, 10(3), pp.305-316. https://doi.org/10.5367/0000000041895094 
Dritsakis, N., Varelas, E. \& Adamopoulos, A., (2006). The main determinants of economic growth: An empirical investigation with Granger causality analysis for Greece. European Research Studies Journal, 9(3-4), pp.47-58.

Dunning, J.H., (1979). Explaining changing patterns of international production: in defence of the eclectic theory. Oxford bulletin of economics and statistics, 41(4), pp.269-295. https://doi.org/10.1111/j.1468-0084.1979.mp41004003.x

Dunning, J.H., (1980). Towards an eclectic theory of international production: some empirical tests. Journal of international business studies, 11(1), pp.9-31. https://doi.org/10.1057/palgrave.jibs.8490593

Dunning, J.H., (1981). Explaining The International Direct Investment Position Of Countries: Towards A Dynamic Or Developmental Approach.Weltwirtschaftliches Archiv, 117(1), Pp.30-64. https://doi.org/10.1007/BF02696577

Dunning, J.H., (1988). The eclectic paradigm of international production: a restatement and some possible extensions. Journal of international business studies, pp.1-31. https://doi.org/10.1057/palgrave.jibs.8490372

Dunning, J.H., (2003). Some Antecedents Of Internalization Theory. Journal Of International Business Studies, 34(2), Pp.108115.

https://doi.org/10.1057/palgrave.jibs. 8400010

Engle R.F. \& Granger C.W.J., (1987). Cointegration and error correction: Representation, estimation and testing. Econometrica, 55:251-276. https://doi.org/10.2307/1913236

Furceri, D. \& Mourougane. A., (2009). "The Effect of Financial Crises on Potential Output: New Empirical Evidence from OECD Countries," Journal of Macroeconomics, 34(3), 822832. https://doi.org/10.1016/j.jmacro.2012.05.010

Goel, R.K. \& Koehonen, I., (2012). Economic growth in BRIC countries and comparisons with rest of the world-Crescita economica nei paesi BRIC e confronti con il resto del mondo. Economia Internazionale/International Economics, 65(3), pp.447-471.

Goldman Sachs. (2001). Building Better Global Economic BRICs. Accessed from http://www.goldmansachs.com/ourthinking/topics/brics/brics-reports-pdfs/build-betterbrics

Granger, C. W. J. (1988). Some Recent Developments in a Concept of Causality, Journal of Econometrics, 39 (1-2): 199-211. https://doi.org/10.1016/0304-4076(88)90045-0

Gros, D. \& Alcidi, C., (2010). The impact of the financial crisis on the real economy. Intereconomics, 45(1), pp.4-20. https://doi.org/10.1007/s10272-010-0320-0

Gujarati, D.N. \& Porter, D., (2009). Basic Econometrics Mc Graw-Hill International Edition.

Hassan, A.M.H., 2003. Financial integration of stock markets in the Gulf: a multivariate cointegration analysis. International Journal of Business, 8(3).

https://doi.org/10.2139/ssrn.420246
Im, K. S., Pesaran, M. H., \& Shin, Y., (2003). Testing for Unit Roots in Heterogeneous Panels. Journal of Econometrics, 115 (1): 53-74. https://doi.org/10.1016/S0304-4076(03)00092-7

Jadhav, P., (2012). Determinants of foreign direct investment in BRICS economies: Analysis of economic, institutional and political factor. Procedia-Social and Behavioral Sciences, 37, pp.5-14. https://doi.org/10.1016/j.sbspro.2012.03.270

Ksantini, M. \& Boujelbène, Y., (2014). Impact of Financial Crises on Growth and Investment: An Analysis of Panel Data. Journal of International and Global Economic Studies, 7(1), PP. 3257.

Levin, A., Lin, C. F. \& Chu, C. S., (2002). Unit Root Tests in Panel Data: Asymptotic and Finite Sample Properties. Journal of Econometrics, 108 (1): 1-24. https://doi.org/10.1016/S0304-4076(01)00098-7

Maddala, G.S. and Wu, S., (1999). A comparative study of unit root tests with panel data and a new simple test. Oxford Bulletin of Economics and statistics, 61(S1), pp.631-652. https://doi.org/10.1111/1468-0084.61.s1.13

OECD Working Paper, No. 699.

Paramati, S.R., Alam, M.S. and Chen, C.F., (2016). The Effects of Tourism on Economic Growth and $\mathrm{CO} 2$ Emissions A Comparison between Developed and Developing Economies. Journal of Travel Research, p.0047287516667848 https://doi.org/10.1177/0047287516667848

Paul, J. \& Ichinoise, R., (2014). Impact of global recession on developed and BRIC countries. Available at SSRN 2429146. https://doi.org/10.2139/ssrn.2429146

Pedroni, P., (1995). 'Panel Cointegration; Asymptotic and Finite Sample Properties of Pooled Time Series Tests, with an Application to the PPP Hypothesis', Indiana University Working Papers in Economics, No. 95-013, June.

Pedroni, P., (1998). 'Testing for Convergence to Common Steady States in Nonstationary Heterogeneous Panels', Working Paper, Indiana University, November.

Pedroni, P., (2004). Panel Cointegration: Asymptotic and Finite Sample Properties of Pooled Time Series Tests with an Application to the PPP Hypothesis: New Results. Econometric Theory, 20 (3): 597-627. https://doi.org/10.1017/S0266466604203073

Thangavelu, S.M., Wei Yong, Y. \& Chongvilaivan, A., (2009). FDI, growth and the Asian financial crisis: the experience of selected Asian countries. The World Economy, 32(10), pp.1461-1477. https://doi.org/10.1111/j.1467-9701.2009.01202.x

Received on 01-10-2019

Accepted on 13-11-2019

Published on 27-12-2019

\section{DOI: https://doi.org/10.6000/1929-7092.2019.08.114}

(C) 2019 Oche et al.; Licensee Lifescience Global.

This is an open access article licensed under the terms of the Creative Commons Attribution Non-Commercial License (http://creativecommons.org/licenses/by-nc/3.0/) which permits unrestricted, non-commercial use, distribution and reproduction in any medium, provided the work is properly cited. 